\title{
2021 Kuznets Prize awarded to Yun Qiu, Xi Chen, and Wei Shi
}

Published online: 18 September 2020

(C) Springer-Verlag GmbH Germany, part of Springer Nature 2020

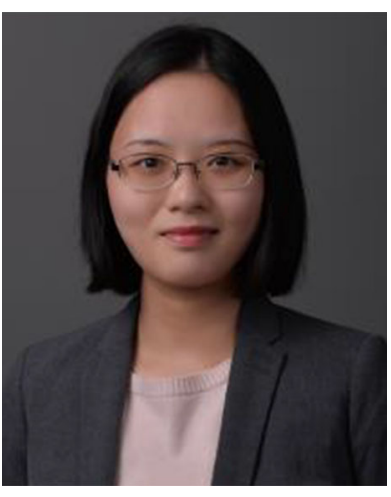

Yun Qiu

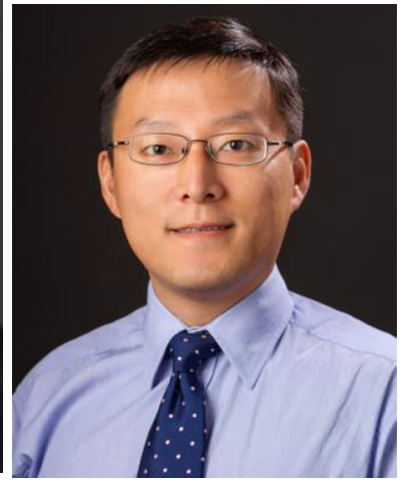

Xi Chen

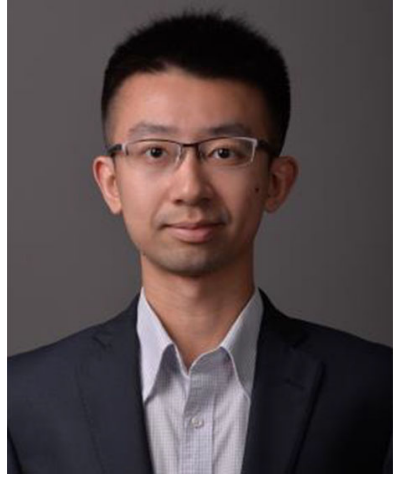

Wei Shi

Yun Qiu (Jinan University), Xi Chen (Yale University), and Wei Shi (Jinan University) have received the 2021 Kuznets Prize for their article "Impacts of social and economic factors on the transmission of coronavirus disease 2019 (COVID-19) in China," which was published in the Journal of Population Economics (2020), 33(4), pp. 1127-1172. The annual prize honors the best article published in the Journal of Population Economics in the previous year.

\section{Biographical abstracts}

Yun Qiu is an assistant professor at the Institute for Economic and Social Research at Jinan University (Guangzhou, China). She obtained a PhD in Agricultural, Environmental, and Development Economics from Ohio State University. She is a Fellow of the Global Labor Organization (GLO). Yun uses applied econometric techniques to conduct research in areas focused on (1) understanding the health and productivity impacts of extreme weather and air pollution in China; (2) characterizing the influencing factors of the spread of COVID-19 and its socioeconomic impacts; and (3) valuing coastal adaptation strategies and urban amenities. 
Xi Chen is an associate professor of Health Policy and Economics at Yale University. He obtained a PhD in Applied Economics from Cornell University. His research endeavors focus on improving public policies on population aging, life course health, and global health systems. Dr. Chen is a consultant at the United Nations Institutions, Fellow at the Global Labor Organization (GLO), former President of the China Health Policy and Management Society, and Butler-Williams Scholar at the US National Institutes of Health. Dr. Chen's work has been published in prestigious economics, science, and medical journals, recognized through numerous awards, and widely covered in media.

Wei Shi is an associate professor at the Institute for Economic and Social Research, Jinan University (Guangzhou, China). His research interests include topics in econometrics, real estate economics, and applied microeconomics. His current research focuses on panel data models with spatial interactions and multidimensional heterogeneities, peer effects models, and applications of spatial econometric models. He is a Fellow of the Global Labor Organization (GLO) and obtained his $\mathrm{PhD}$ in economics from Ohio State University.

\section{Abstract of the winning paper}

"This study models local and cross-city transmissions of the novel coronavirus in China between January 19 and February 29, 2020. We examine the role of various socioeconomic mediating factors, including public health measures that encourage social distancing in local communities. Weather characteristics 2 weeks prior are used as instrumental variables for causal inference. Stringent quarantines, city lockdowns, and local public health measures imposed in late January significantly decreased the virus transmission rate. The virus spread was contained by the middle of February. Population outflow from the outbreak source region posed a higher risk to the destination regions than other factors, including geographic proximity and similarity in economic conditions. We quantify the effects of different public health measures in reducing the number of infections through counterfactual analyses. Over 1.4 million infections and 56,000 deaths may have been avoided as a result of the national and provincial public health measures imposed in late January in China."

\section{About the Kuznets prize}

The Journal of Population Economics awards the "Kuznets Prize" for the best paper recently published in the Journal of Population Economics. Starting from 2014, the Prize has been awarded annually. Papers are judged by the Editors of the Journal.

Simon Kuznets, a pioneer in population economics, Professor Emeritus at Harvard University, and the 1971 Nobel Prize laureate in economics, died on July 10, 1985. Professor Kuznets was born 1901 in Pinsk, Belarus, and came to the USA in 1922. He earned his Bachelor of Science in 1923, a Master of Arts degree in 1924, and his doctorate in 1926, all from Columbia University. During World War II, he was Associate Director of the Bureau of Planning and Statistics on the War Production 
Board, and he served on the staff of the National Bureau of Economic Research from 1927 to 1960 . Mr. Kuznets was a faculty member at the University of Pennsylvania for 24 years and Professor of Political Economy at Johns Hopkins University from 1954 until he joined Harvard University in 1960. He retired in 1971 and was given the title of George F. Baker Professor Emeritus of Economics. He was a former president of the American Economic Association and the American Statistical Association.

\section{Previous winners}

The Kuznets Prize has previously been awarded to:

2020: Gautam Hazarika (University of Texas Rio Grande Valley), Chandan Kumar Jha (Le Moyne College, Madden School of Business), and Sudipta Sarangi (Virginia Tech) for their article "Ancestral ecological endowments and missing women," Journal of Population Economics 32(4): pp. 1101-1123.

2019: Yoo-Mi Chin (Baylor University) and Nicholas Wilson (Reed College) for their article "Disease risk and fertility: evidence from the HIV/AIDS pandemic," Journal of Population Economics 31(2): pp. 429-451.

2018: Chunbei Wang and Le Wang (University of Oklahoma) for their article "Knot yet: Minimum marriage age law, marriage delay, and earnings," Journal of Population Economics 30(3): pp. 771-804.

2017: Binnur Balkan (Stockholm School of Economics) and Semih Tumen (Central Bank of the Republic of Turkey) for their article "Immigration and prices: quasiexperimental evidence from Syrian refugees in Turkey," Journal of Population Economics 29(3): pp. 657-686.

2016: Loren Brandt (University of Toronto), Aloysius Siow (University of Toronto), and Hui Wang (Peking University) for their article "Compensating for unequal parental investments in schooling," Journal of Population Economics 28: 423-462.

2015: Haoming Liu (National University of Singapore) for his article "The qualityquantity trade-off: evidence from the relaxation of China's one-child policy," Journal of Population Economics 27: 565-602.

2014: Paolo Masella (University of Essex) for his article "National Identity and Ethnic Diversity,", Journal of Population Economics 26: 437-454.

Period 2010-2012: Richard W. Evans (Brigham Young University), Yingyao Hu (Johns Hopkins University), and Zhong Zhao (Renmin University) for their article "The fertility effect of catastrophe: US hurricane births," Journal of Population Economics 23: 1-36.

Period 2007-2009: Makoto Hirazawa (Nagoya University) and Akira Yakita (Nagoya University) for their article "Fertility, child care outside the home, and pay-asyou-go social security," Journal of Population Economics 22: 565-583.

Period 2004-2006: Jinyoung Kim (Korea University) received the Kuznets Prize for his article "Sex selection and fertility in a dynamic model of conception and abortion," Journal of Population Economics 18: 041-067.

Period 2001-2003: Olympia Bover (Bank of Spain) and Manuel Arellano (CEMFI), for their article "Learning about migration decisions from the migrants: Using complementary datasets to model intra-regional migrations in Spain", Journal of Population Economics 15:357-380. 
Period 1998-2000: David C. Ribar (The George Washington University), for his article "The socioeconomic consequences of young women's childbearing: Reconciling disparate evidence," Journal of Population Economics 12: 547-565.

Period 1995-1997: James R. Walker (University of Wisconsin-Madison), for his article "The effect of public policies on recent Swedish fertility behavior," Journal of Population Economics, 8: 223-251.

Publisher's note Springer Nature remains neutral with regard to jurisdictional claims in published maps and institutional affiliations. 